\title{
FYN wt Allele
}

National Cancer Institute

\section{Source}

National Cancer Institute. FYN wt Allele. NCI Thesaurus. Code C51117.

Human FYN wild-type allele is located within $6 \mathrm{q} 21$ and is approximately $212 \mathrm{~kb}$ in length.

This allele, which encodes proto-oncogene tyrosine-protein kinase Fyn protein, is involved

in protocadherin signaling and regulation of T-cell signaling. 